\title{
Nilai Prognostik FLT3 Pada Pasien Leukemia Mieloid Akut
}

\author{
Hendra Asputra*
}

\begin{abstract}
Acute myeloid leukemia (AML) is a disease characterized by neoplastic transformation and abnormality of progenitor cells differentiation from myeloid cells. In AML there is a heterogeneous abnormality in hematopoietic progenitor cells, this abnormality has been identified and affects the balance between proliferation, survival and differentiation of body cells. Mutation of FMS-like tyrosin kinase 3 (FLT3) gene causes overexpression which is one of the most often found mechanism that has been identified could trigger genetic changes that can disturb intracellular signaling tissue in pathogenesis of leukemia. Besides being used as a diagnostic tool, FLT3 overexpression can also be used to assess the prognosis of AML.
\end{abstract}

Keywords: FLT3, Acute Myeloid Leukemia

Leukemia mieloid akut (LMA) adalah suatu penyakit yang ditandai dengan transformasi neoplastik dan gangguan diferensiasi sel-sel progenitor dari sel mieloid. Bila tidak diobati, penyakit ini akan menyebabkan kematian secara cepat dalam waktu beberapa minggu sampai bulan sesudah diagnosis. ${ }^{1,2}$

Insidensi leukemia mieloid akut (LMA) terjadi sekitar 30\% dari semua leukemia pada orang dewasa, dan sekitar 18.300 kasus baru didiagnosis di Eropa setiap tahun, sekitar $0,6 \%$ dari semua kanker. Di United State (US) tahun 2011, didapatkan insidensi LMA sebanyak 25.320 kasus per tahun dengan angka mortalitas sebanyak 12.740 kasus per tahun, dan merupakan $80 \%$ dari semua leukemia pada dewasa. European Society Medical Oncologi (ESMO) tahun 2005 melaporkan insidensi LMA sebanyak 5-8/100.000 populasi dengan angka mortalitas 4-6/100.000 populasi. Sedangkan di RS Kanker Dharmais tahun 2006 dilaporkan kejadian LMA sebesar 53,3\% dari seluruh leukemia. Secara keseluruhan, LMA adalah leukemia yang paling umum pada orang dewasa, dengan angka kejadian lima kali lebih sering pada usia dibawah 50 tahun.

\footnotetext{
* Corresponding author: hendraasputra_dr@yahoo.co.id

1 KJFD Ilmu Penyakit Dalam Fakultas Kedokteran Universitas Riau/ RSUD Arifin Achmad Provinsi Riau, Pekanbaru, Riau, Indonesia.
}

Terlihat kecenderungan insidensi LMA semakin lama semakin meningkat. ${ }^{3,4}$

Kemajuan dalam sel dan biologi molekular telah merevolusi pemahaman kita tentang hematopoeisis normal. Secara umum survival, proliferasi dan diferensiasi adalah tiga proses selular yang mendasari perkembangan sel hematopoeitik normal. ${ }^{5,6}$ Pada LMA terdapat kelainan heterogen pada sel progenitor hematopoeitik, kelainan ini telah diidentifikasi dan mempengaruhi keseimbangan antara proliferasi, survival dan diferensiasi sel. Kelainan ini mengakibatkan ekspansi dari klon sel induk abnormal. Selama beberapa tahun terakhir, beberapa studi telah menyimpulkan bahwa leukemogenesis adalah proses di mana beberapa kegiatan yang meliputi perubahan genetik independen pada proto-onkogen atau gen-supressor, bersama dengan faktor epigenetik atau faktor lingkungan, yang berkontribusi pada perkembangan fenotip ganas. ${ }^{7,8}$

Meskipun banyak kontrol yang mengatur hematopoeisis, mutasi pada gen regulator mampu mempromosikan leukemogenesis. FLT3 reseptor tirosin kinase encode memainkan peran penting dalam mengontrol kelangsungan hidup, proliferasi dan diferensiasi sel hematopoitik. Overekspresi pada gen ini dapat menyebabkan deregulasi keseimbangan antara proliferasi dan diferensiasi sel. ${ }^{8,9}$ 
Mutasi gen FMS-like tirosin kinase 3 (FLT3) menyebabkan overekspresi yang merupakan salah satu dari yang paling sering diidentifikasi dari perubahan genetik yang mengganggu jaringan signaling intraselular yang berperan dalam patogenesis leukemia. Overekspresi FLT3 selain digunakan sebagai alat diagnosis, juga dapat digunakan untuk menilai prognosis. Oleh karena relevansinya dengan prognostik, klasifikasi dari World Health Organization (WHO) saat ini merekomendasikan penilaian mutasi gen FLT3 untuk semua pasien dengan LMA. Berikut penulis paparkan tinjauan pustaka mengenai nilai prognostik FLT3 pada pasien LMA.

\section{Epidemiologi LMA}

Leukemia mieloid akut adalah kategori penyakit yang ditandai dengan kelainan imunofenotip dan heterogenisitas dari genetik, yang didefinisikan sebagai proliferasi sel klon imatur dari progenitor hematopoitik dengan diferensiasi mieloid (myeloblast) di sumsum tulang, darah perifer atau jaringan ekstramedular. Secara epidemiologi, LMA menunjukkan distribusi tertinggi di kelompok usia muda. Pada usia yang lebih tua LMA terjadi sekitar $25 \%$ dari semua kasus leukemia. ${ }^{5,6,7}$

Tabel 1. Mutasi kelas I, II dan tidak terklasifikasi ${ }^{12}$

\section{Patogenesis LMA}

Patogenesis utama LMA adalah adanya blokade maturitas yang menyebabkan proses diferensiasi sel-sel seri mieloid terhenti pada sel-sel muda (blast) dengan akibat terjadi akumulasi blast di sum-sum tulang. Akumulasi blast dalam sum-sum tulang akan menyebabkan gangguan hematopoesis normal dan pada gilirannya akan mengakibatkan sindroma kegagalan sum-sum tulang (bone marrow failure syndrome) yang ditandai dengan adanya sitopenia (anemia dan trombositopenia). Adanya anemia menyebabkan pasien mudah lelah dan pada kasus yang lebih berat bisa sesak nafas, adanya trombositopenia akan menyebabkan tandatanda perdarahan, sedangkan adanya leukopenia akan menyebabkan pasien akan rentan terhadap infeksi, termasuk infeksi opurtunistik dari flora bakteri normal yang ada di dalam tubuh manusia. Selain itu sel-sel blast yang terbentuk juga punya kemampuan untuk migrasi keluar sum-sum tulang dan berinfiltrasi ke organ-organ lain seperti kulit, tulang, jaringan lunak dan sistem saraf pusat dan merusak organ-organ tersebut dengan segala akibatnya. ${ }^{10,11}$

Hal mendasari blokade maturitas ini adalah kelainan genetik yang disebabkan oleh mutasi gen. Mutasi gen ini dibagi atas mutasi kelas I, kelas II dan unclassified seperti yang terlihat pada tabel dibawah ini.

\begin{tabular}{ccc}
\hline Mutasi Kelas I & Mutasi Kelas II & Mutasi Tak Terklasifikasi \\
\hline Mutasi FLT3 & PML-RARa & NPM1 \\
Mutasi c-KIT & AML 1-ETO & Dnmt3a \\
Mutasi N-or K-Ras & CBFb-MYH11 & \\
PTPN11 & Mtuasi AML1 & \\
& Mutasi C/EBPa & \\
& MLL-PTD & \\
\hline
\end{tabular}

\section{Manifestasi Klinis LMA}

Tanda dan gejala utama LMA adalah rasa lelah, perdarahan dan infeksi yang disebabkan sindroma kegagalan sumsum tulang. Perdarahan biasanya terjadi dalam bentuk purpura atau ptekie yang sering dijumpai di ekstrimitas bawah atau berupa epistaksis, perdarahan gusi atau retina. Perdarahan yang lebih berat jarang terjadi kecuali pada kasus yang disertai dengan DIC. Kasus DIC ini paling sering dijumpai pada kasus LMA tipe M3. Infeksi sering terjadi di tenggorokan, paru-paru, kulit dan daerah perirektal. ${ }^{10,11}$

Leukositosis terjadi pada lebih dari 50\% kasus LMA, sekitar $15 \%$ pasien mempunyai angka leukosit yang normal dan sekitar 35\% pasien mengalami neutropenia, meskipun demikian sel-sel blast dalam jumlah yang signifikan dalam sel-sel darah tepi akan ditemukan pada lebih $85 \%$ kasus LMA. Pada pasien dengan angka leukosit yang sangat tinggi (lebih dari $100.000 / \mathrm{mm}^{3}$ ), sering terjadi leukostasis, 
yaitu terjadinya gumpalan leukosit yang menyumbat aliran pembuluh darah vena maupun arteri. Gejala leukostasis sangat bervariasi, tergantung lokasi sumbatannya. Angka leukosit yang sangat tinggi juga sering menimbulkan gangguan metabolisme berupa hiperurisemia dan hipoglikemia. Infiltasi sel-sel blast akan menyebabkan tanda/gejala yang bervariasi tergantung organ yang diinfiltrasi. ${ }^{10,11}$

\section{Diagnosis LMA}

Pendekatan diagnostik pada leukemia akut telah terjadi perubahan yang signifikan selama 20-30 tahun terakhir, dan mencerminkan kemajuan dalam pemahaman tentang perubahan genetik dan molekuler yang berkontribusi pada leukemogenesis. ${ }^{10,11}$

Secara garis besar diagnostik kerja leukemia akut yaitu berdasarkan pemeriksaan sumsum tulang pada pasien yang dicurigai berdasarkan klinis dan laboratorium. Kemudian dapat dilakukan pemeriksaan morfologi, sitokimia dan immunofenotip. Setelah itu dapat dilakukan pemeriksaan lanjutan yaitu pemeriksaan sitogenetik dan molekuler, namun ini membutuhkan waktu yang agak lama, namun hasil yang diperoleh dapat digunakan untuk klasifikasi dan diagnosis definitif penyakit. ${ }^{10,11}$

Secara klasik diagnosis LMA ditegakkan berdasarkan pemeriksaan fisik, morfologi sel dan pengecatan sitokimia dan ada pemeriksaan terbaru yaitu immunophenotyping dan analisis sitogenetik. Berdasarkan pemeriksaan morfologi dan pengecatan sitokimia, gabungan ahli hematologi Amerika, Perancis dan Inggris menetapkan klasifikasi LMA yang terdiri dari 8 subtipe (M0 sampai M7). Klasifikasi ini dikenal dengan nama klasifikasi FAB (French American British). Klasifikasi FAB hingga saat ini masih menjadi diagnosis dasar LMA. Pengecatan sitokimia yang penting untuk pasien LMA adalah Sudan Black B (SBB) dan Mieloperoksidase (MPO). Kedua pengecatan sitokimia tersebut akan memberikan hasil positif pada pasien LMA tipe M1, M2, M3, M4 dan M6. ${ }^{10,11,13}$

Tabel 2. Klasifikasi LMA berdasarkan $F A B^{10}$

\begin{tabular}{ll}
\hline \multicolumn{1}{c}{ Subtipe } & Diagnosis \\
\hline Mo & Acute undifferentiated leukemia \\
M1 & AML with minimal differentiation \\
M2 & AML with differentiation \\
M3, M3V & Acute promyeloctic leukemia, microgranular variant \\
M4, M4eo & Acute myeloctic leukemia, with abnormal eosinophilis \\
M5a, M5b & Acute monoblastic leukemia poorly differentiated, with differentiation \\
M6 & Acute erythroleukemia \\
M7 & Acute megakaryoblastic leukemia \\
\hline
\end{tabular}

Zuo Z et al (2009) merekomendasikan langkahlangkah dalam menegakkan diagnosis leukemia akut seperti terlihat pada gambar berikut ini. ${ }^{6}$

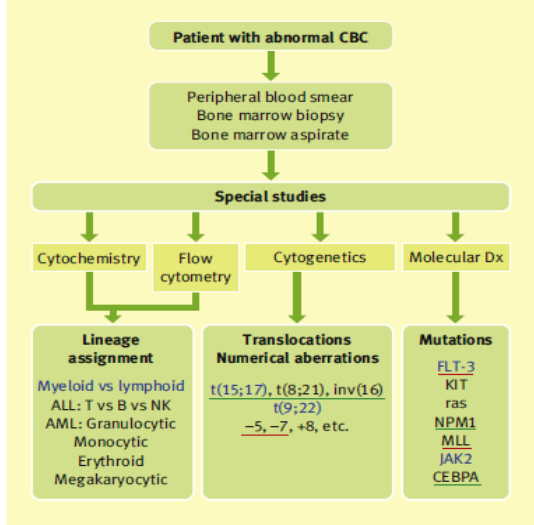

Gambar 1. Pemeriksaan sitokimia, sitogenetik dan molekuler pasien leukemia akut. ${ }^{6}$
Terlihat bahwa upaya dalam menegakkan diagnosis leukemia akut memerlukan pemeriksaan sitomorfologi, sitokimia, immunophenotyping dengan flowcytometry, sitogenetik dan molekuler.

\section{Penyimpangan kromosom, mutasi gen, perubahan ekspresi dan prognosis pada leukemia mieloid akut}

Leukemia mieloid akut (LMA) adalah proses multistep yang memerlukan kolaborasi minimal dua kelas mutasi, terdiri dari mutasi kelas I yang mengaktifkan jalur sinyal transduksi yang berpengaruh pada proliferasi sel-sel hematopoeitik dan atau survival sel serta mutasi kelas II yang mempengaruhi faktor transkripsi dan merusak 
diferensiasi sel hematopoitik. Analisis komprehensif pada penelitian Ishikawa et al, pada 144 pasien LMA yang baru didiagnosis didapatkan bahwa terdapat overlapping mutasi antara mutasi kelas I dan kelas II. Selain sering terjadinya mutasi pada $F L T 3$ itu sendiri, juga terdapat mutasi dengan molekul lain (misalnya NPM1, c-KIT, CBFB/MYH11 rearrangement), mereka menemukan bahwa 2 dari 35 pasien dengan mutasi FLT3 juga memiliki mutasi pada NPM-1, c-KIT dan AML1/ETO. Secara kolektif, mutasi FLT3 memainkan peran kunci dalam leukemogenesis yang bekerja sama secara fungsional dengan molekul lain. $6,7,10,12,13,14$

\section{Struktur FLT3}

Reseptor FLT3 (Fms-like tirosin kinase 3), juga dikenal sebagai FLK2 (fetal liver tyrosine kinase 2), STK-1 (stem cell tyrosine kinase 1) atau CD135, dikodekan oleh gen FLT3 pada kromosom 13q12. Gen ini terdiri dari 24 ekson dan mencakup sekitar $96 \mathrm{~kb}$, ukuran pasti belum diketahui karena adanya intron besar $(>50 \mathrm{~kb})$ terletak antara ekson 2 dan 3. Panjang transkripsi yaitu $3.7 \mathrm{~kb}$ dan berisi pseudogene dengan rangka terbuka membaca 2979 bp. Protein yang mengkodekan adalah reseptor transmembran dari 933 asam amino dengan berat molekul 155-160 kDa yang merupakan kelas III family reseptor tyrosine kinase (RTK). ${ }^{12,14,15}$

Struktur FLT3 terdiri dari empat daerah (gambar 2), yaitu ${ }^{12,14,15}$ :

a) N-terminal ekstraselular region (541aa) terdiri dari 5 immunoglobulin-like domain, dimana tiga paling distal dari membran plasma yang terlibat dalam pengikatan ligan, sementara domain proksimal terlibat dalam dimerisasi dari reseptor

b) Transtransmembrane portion (21aa)

c) Juxtamembrane (JM) domain

d) Intraselular C-terminal region (431aa) dengan split kinase domain.

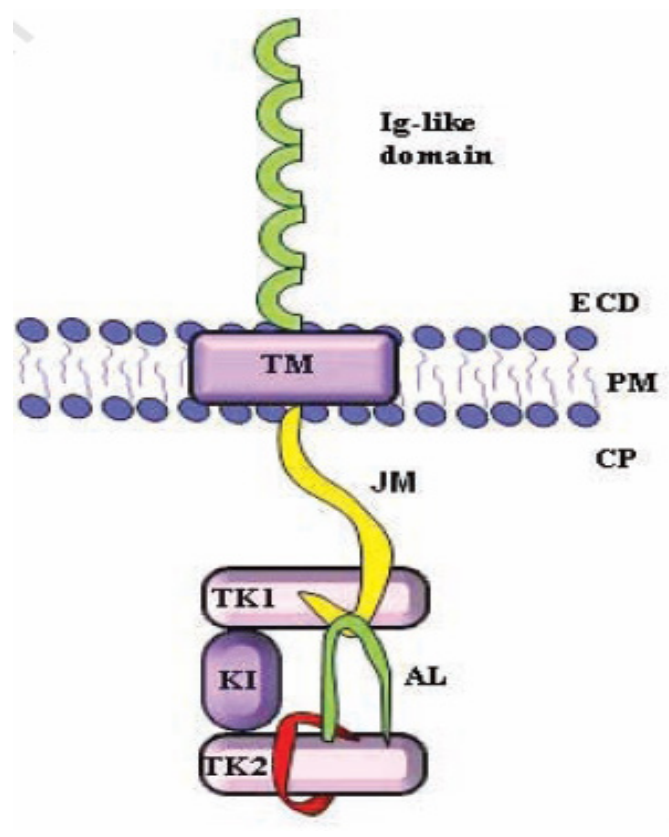

Gambar 2. Struktur FLT3. 12,21,27

\section{FLT3 ligand}

Eksposur FLT3 pada ligan merupakan langkah penting dalam mengatur kegiatan reseptor. $F L$ merupakan protein transmembran tipe 1, bagian dari faktor pertumbuhan yang merangsang proliferasi dan diferensiasi sel hematopoietik. . $^{16,17,18}$

Ada dikenal tiga isoforms:

1) Glikoprotein $30 \mathrm{kDa}$ dengan empat transmembran alfa-heliks, domain aminoterminal dan area sitoplasmik, yang merupakan bentuk yang paling sering, untuk mengikat dan mengaktifkan reseptor.

2) Biologis aktif yang larut, dihasilkan melalui pemotongan isoform transmembran

3) Dalam bentuk larut.

$F L$ diekspresikan oleh sebagian besar jaringan, termasuk organ pembentuk darah (limpa, timus, darah perifer dan sumsum tulang), prostat, ovarium, ginjal, paru-paru, colon, usus kecil, testis, hati dan plasenta, dengan tingkat ekspresi yang lebih tinggi pada permukaan sel blast sum-sum tulang dan darah perifer. ${ }^{16,17}$

Aktifitas $F L$ akan minimal ketika bertindak sendirian, tapi itu sangat sinergis dengan sitokin 
lain. Pada leukemia mieloid akut, rangsangan FLT3 oleh ligan yang mempromosikan proliferasi dan kelangsungan hidup sel blast leukemia diekspresikan oleh reseptor. Progenitor hematopoietik dapat dirangsang oleh sekresi lokal $F L$ atau dari kontak langsung dengan $F L$ yang diekspresikan pada permukaan sel mononuklear, ini menunjukkan kontrol dari aktivasi FLT3 melalui loop paracrine atau kontrol umpan balik autocrin. ${ }^{13,14}$

\section{Jaringan sinyal transduksi yang diaktifkan FLT3}

Ekspresi FLT3 memiliki peran penting dalam banyak proses regulasi sel hematopoeitik, termasuk metabolisme fosfolipid, transkripsi, proliferasi, apoptosis, dan hubungan dengan jalur $R A S$ dan juga terlibat dalam leukemogenesis, seperti yang terlihat pada gambar 3. FLT3 menyebabkan aktivasi jaringan sinyal transduksi terutama melalui phospatidylinositol-3-kinase (PI3K) dan kaskade $R A S$, mendukung aktivasi $A K T$ (protein kinase $B$, $P K B$ ), signal transduser and activator transcription factor (STAT) dan ekstraselular signal regulated kinase 1 dan 2 (ERK1/2). ${ }^{13,14,17}$

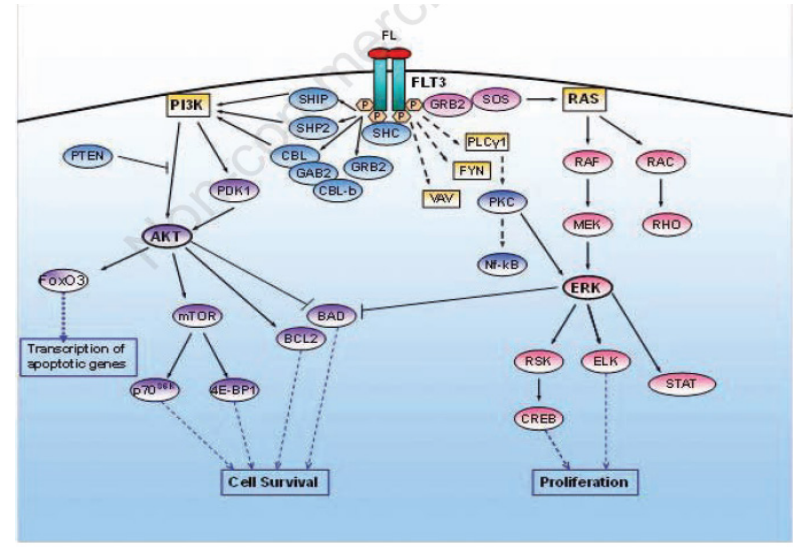

Gambar 3. Jalur aktivasi sinyal oleh FLT3-WT ${ }^{7}$.

Dalam keadaan tidak terstimulasi, reseptor FLT3 ada dalam bentuk monomer, dalam bentuk tidak terfosforilasi dengan bagian kinase inaktif. Pada interaksi reseptor dengan FLT3 ligan (FL), reseptor mengalami perubahan konformasi, yang menyebabkan pemaparan dari domain dimerisasi, yang memungkinkan dimerisasi reseptor-reseptor untuk mengambil tempat. Dimerisasi reseptor ini adalah awal dari aktivasi enzim tirosin kinase, yang menyebabkan fosforilasi berbagai situs di domain intraseluler. ${ }^{13,14,17}$

Reseptor yang teraktivasi merekrut sejumlah protein dalam sitoplasma untuk membentuk kompleks interaksi protein-protein dalam domain intraseluler. Protein $S H C, G R B 2, S H I P, C B L$, dan CBLB adalah beberapa dari banyak protein adaptor yang berinteraksi dengan reseptor FLT3 yang teraktivasi. Karena setiap protein mengikat kompleks, akan menjadi aktif pada gilirannya, yang menghasilkan kaskade reaksi fosforilasi yang memuncak dalam aktivasi dari sejumlah mediator sekunder, termasuk jalur sinyal transduksi $M A P$ kinase, STAT, dan AKT. Sekali diaktifkan, mediator yang teraktivasi ini dikawal ke nuklir interfase oleh HSP90, dalam pemindahan pesan ke nukleus. Pada inti ini mediator transkripsi memicu serangkaian peristiwa yang berpuncak pada regulasi diferensiasi sel, proliferasi apoptosis, dan kelangsungan hidup sel (Gambar 4). ${ }^{13,14,17}$

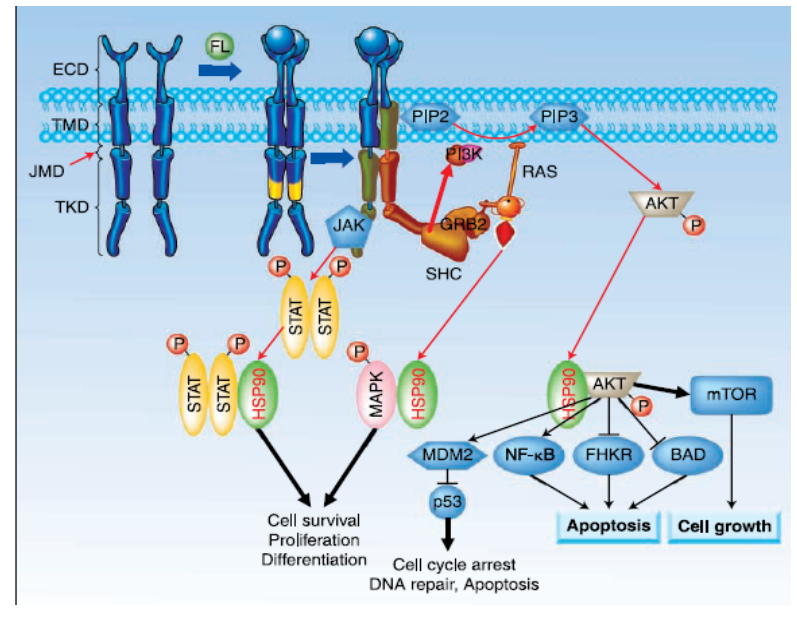

Gambar 4. Jalur aktivasi sinyal oleh FLT3. ${ }^{17}$

\section{FLT3 dan Leukemia Mieloid Akut}

FMS-like tyrosine kinase 3 (FLT3) diekspresikan pada tingkat tinggi dalam beberapa spektrum keganasan hematologik, yaitu 93\% dari kasus LMA. Ini menunjukkan bahwa overekspresi reseptor ini dapat berperan dalam kelangsungan hidup dan proliferasi dari sel leukemia. Data ini menunjukkan bahwa signaling FLT3 penting dalam subtipe leukemia tertentu dan juga terlibat dalam jalur signaling autocrine, paracrine atau intracrine. ${ }^{13,14,19,20}$

Dalam beberapa tahun terakhir, telah menunjukkan bahwa somatic activation mutation 
dari gen FLT3 merupakan kelainan genetik yang paling umum pada LMA dan memiliki dampak yang signifikan pada prognosis. Sekitar 30-70\% dari kasus yang diagnosis LMA memiliki mutasi gen FLT3, secara khusus 70\% dari pasien dengan normal kariotipe dan $35 \%$ dari pasien dengan $\mathrm{t}(15 ; 17)$, dan frekuensi lebih tinggi pada de novo LMA. Pasien wanita lebih sering, dan mutasi ini dikaitkan dengan hiperselularitas dan insiden rekurensi yang tinggi. ${ }^{13,14,19,20}$

Perubahan genetik pada FLT3 akan menyebabkan ekspresi constitutive dari activated tyrosine kinase receptor pada blast LMA, dan aktivasi ini menyebabkan leukemogenesis, mengatur karakteristik fungsional dari blast leukemia. Pada pasien LMA terdapat dua jenis utama yang mengaktifkan mutasi, ITD di daerah coding untuk domain $J M$, ditentukan oleh urutan masuknya asam amino yang berulang-ulang, dan titik mutasi yang menyebabkan substitusi asam amino dalam lingkaran aktivasi $T K D \cdot{ }^{19,20}$

\section{PENUTUP}

Pasien AML dengan mutasi pada FLT 3 memiliki prognosis yang lebih buruk daripada pasien tanpa mutasi pada FLT3. Mutasi pada gen FLT3 merupakan salah satu dari yang paling sering diidentifikasi dari perubahan genetik yang berperan dalam patogenesis leukemia mieloid akut. Oleh karena itu perlunya pemeriksaan FLT3 pada pasien yang didiagnosis AML sehingga dapat menentukan prognosis dan sekaligus rencana terapi target.

\section{DAFTAR PUSTAKA}

1. Wetzler M. Acute and chronic myeloid leukemia. Harrisons principles of internal medicine. $16^{\text {th }}$ edition. Mc graw Hill. 2005;1:631-641.

2. Mehta A \& Hoffbrand V. Leukemia akut. Klasifikasi dan diagnosis. At a glance hematology. Airlangga. 2008;2:52-3.

3. Suzanna E, Sirait T, Rahayu PS, Shalmont G, Anwar E, Andalusia R, et al. Registrasi kanker berbasis rumah sakit di rumah sakit kanker dharmais. Pusat kanker nasional. Indonesian Journal of Cancer 2012;6(4):181-196.
4. Fey MF, Greil R, Jost LM. ESMO Clinical recommendations for the diagnosis, treatment and follow-up of acute myeloblastic leukemia (AML) in adult patients. Annals of Oncology 2005;16(1):40-49.

5. Bakta IM. Hematologi Klinik. EGC. Jakarta. 2006:121-149.

6. Zuo Z, Chandra P,Wen YH, Koeppen H. Molecular diagnostics of acute myeloid leukemia. Diagnostic Histopathology 2009:15(11):531-9.

7. Abdel WO \& Zuckerman. Molecular genetics of acute myeloid leukemia: Clinical implications and opportunities for integrating genomics into clinical practice. Hematology 2012:17(1):39-42.

8. Mrozek K \& Bloomfield CD. Chromosome aberrations, gene mutations and expression changes, and prognosis in adult acute myeloid leukemia. Hematology Am Soc Hematol Educ Program 2006;2006(1):169-177.

9. Vora HH, Shukla SN, Brahambhatt BV, Mehta SV, Patel N, Parikh SK, et al. Clinical relevance of FLT3 receptor protein expression in Indian patients with acute leukemia. Asia Pacific Journal Of Clinical Oncology 2010:306-319.

10. Kurnianda J. Leukemia mieloid akut. Dalam Buku Ajar Ilmu Penyakit Dalam Edisi kelima, jilid II, editor Sudoyo A dkk. Interna Publishing, Jakarta. 2009:1234-1240.

11. Smith M, BarnettM, Bassan R, Gemma G, Tondini $\mathrm{C}$ and Kern W. Adult acute myeloid leukemia. Crit rev oncol hematol 2004;50(3):197-222.

12. Takahashi S. Downstream molecular pathways of FLT3 in the pathogenesis of acute myeloid leukemia: biology and therapeutic implications. J Hematol Oncol 2011:1-10.

13. Arber DA, Carter NH, Ikle D and Slovak M. Value of combined morphologic, cytochemical, and immunophenotypic features in predicting recurrent cytogenetic abnormalities in acute myeloid leukemia. Human Pathology 2003;35(5):1-9.

14. Grafone T, Palmisano M, Nicci C, Storti S. An Overview on the Role of FLT3-tyrosine kinase receptor in acute myeloid leukemia: biology and treatment. Oncol Rev 2012;6(1):65-74. 
15. Testa U \& Pelosi E. The Impact of FLT3 mutations on the development of acute myeloid leukemias. Leukemia Research and Treatment 2013:1-14.

16. Kim KT, Levis M, Small D. Constitutively activated FLT3 phosphorylates BAD partially through pim1. Br J Haematol 2006;134:500-9.

17. Ikeda A, Shankar DB, Watanabe M, Tamanoi F, Moore TB, Sakamoto KM. Molecular targets and the treatment of myeloid leukemia. Mol Genet Metab 2006;88(3):216-24.

18. Meshinchi S \& Appelbaum FR. Structural and functional alteration of FLT3 in acute myeloid leukemia. Molecular Pathways. Clin Cancer Res. 2009;15(13):4263-9.
19. Qian Z, Joslin JM, Tennant TR, Reshmi SC, Young DJ, Stoddart A, et al. Cytogenetic and genetic pathways in therapy-related acute myeloid leukemia. Chem Biol Interact 2010;184(0):50-57.

20. Del Poeta, Ammatuna E, Lavorgna S, Capelli G, Zaza S, Luciano F, et al. The genotype nucleophosmin mutated and FLT3-ITD negative is characterized by high $\mathrm{bx} / \mathrm{bcl}-2$ ratio and favourable outcome in acute myeloid leukemia. Br J Haematol 2010;149(3):383-7. 